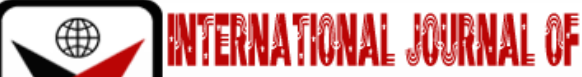

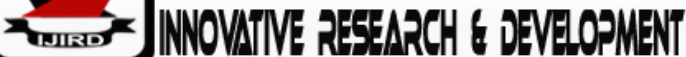

ISSN 2278-0211 (Online)

\section{Efficiency Assessment of Pharmaceutical Industry in Bangladesh: An Application of Data Envelopment Analysis}

\author{
Md. Kazi Golam Azam \\ Assistant Professor, Department of Business Administration, \\ International Islamic University Chittagong, Bangladesh
}

\begin{abstract}
:
Pharmaceutical industry in Bangladesh has significant contribution in both health care facilities and government revenue earnings that impulse assessment of overall performance of this sector to ensure sustainable growth and development. The main purpose of this paper is to investigate economic efficiency growth of pharmaceutical sector with a data of top nine listed companies of Chittagong stock exchange (CSE) during the period of 2015 to 2019. Result of the study postulates poor performance of this industry after application of Malmquist productivity index (MPI) technic using salaries and operational expenses as input variables along with revenue, total asset and net-income as output variables. However, operational efficiency and resource utilization capacity of pharmaceutical industry is notably improved. Further research may be carried out to measure total factor productivity by incorporating all individually owned firm, publicly owned firm and government firm to produce real scenario and further policy formulation in this emerging sector of Bangladesh.
\end{abstract}

Keywords: Malmquist index, efficiency change, total factor productivity index, pharmaceutical industry, Chittagong Stock Exchange (CSE)

\section{Introduction}

Pharmaceutical industry is the vital part of human living that contributing in both health care services and socioeconomic development of an economy. Pharmaceutical industry in Bangladesh is one of the rapid growing sectors, trying to satisfy demand by attaining self-sufficiency in production of medicine. It has annual export earnings of \$27.54 million (approximate) earned from more than 90 countries globally(Haque\& Islam, 2013).The sector is the third largest industry in terms of contribution in government revenue has gained technological development and its considerable growth become more visible in the last two decades. The key factors for this development are derived from the skills, expertise and innovative ideas of professionals working with this industry. About 300 companies are operating that fulfill $97 \%$ local demand for drugs that reduces reliability on foreign goods(Nath, Islam, \& Saha, 2015),(Rashid, 2014).Again, this division become remarkable dynamic business that commits to contribute economic development of Bangladesh. The sedate control Act,1982 is treated as one of the key development variable of this division (Islam \& Khan, 2019).Hence, Pharmaceutical sector is the fastest growing sector, research on this sector is necessary to produce development strategy that helps ensuring sustainable development and expanding this market in global arena. To develop strategy, performance evaluation of this sector considering its core productive factor is necessary and total factor productivity analysis, a nonparametric test helps getting actual scenario of pharmaceutical sector with multiple inputs and outputs. In Bangladesh, privately owned pharmaceutical companies are more dominant than state owned companies. About 300 small, medium and large-scale companies are supplying pharmaceutical products but most of the firms owned by sole trader ship and partnership structure that fails to incorporate mass ownership as well as actual contribution of these firm in pharmaceutical sector cannot be detected in absence of published financial information. Thus, assessment of performance of CSE listed pharmaceutical industry may motivate such firm participate through listing under stock exchange with a view to more capitalize and contribute in the development of pharmaceutical sector in Bangladesh.

The main aim of the study is to test whether there is significant improvement in efficiency change factors of pharmaceutical sector in Bangladesh. The findings of this study highlight evidence of low productivity performance of Pharmaceutical Companies in Bangladesh. Findings of this paper extend research ofDoraisamy \& Azad (2014) who measured the technical efficiency, pure technical efficiency, scale efficiency and total factor productivity change of selected companies during the period of 2014-2019.

The remainder the paper is structured as follows. Section 2 highlights the relevant literature Summarizes previous research on this area section 3 includes methods and methodology. Again, section 4 analyses the result of data and rest of the paper is finished with concluding remarks. 


\section{Literature Review}

A significant number of research has been done on manufacturing industry particularly pharmaceutical industry or medicine industry to measure efficiency of the said industry using DEA method and Total factor productivity(TFP) proposed by(Coelli, Rao, O'Donnell, \&Battese, 2005). The following research proclaims application of DEA methods for firm's efficiency and productivity.(Charnes, Cooper, \& Rhodes, 1978) used data of 36 pharmaceutical company of India to compare technical and scale efficiency differences among state owned, foreign and private enterprises which discovered a significant change. In Kenya,(Kirigia, Emrouznejad, Sambo, Munguti, \& Liambila, 2004)applied DEA method to examine differential technical efficiency based on secondary data of 32 major health care center and conclude forty four percent health care center are technically inefficient. A research done by Khan(2007) on the basis of DEA in order to asses productivity and technical efficiency taking data from 35 pharmaceutical firms with different time period of 1990-1991 and 2004-2005.The output of the study explains that total factor productivity(TFP) is influenced by technical change than other efficiency change. (Saranga \& Phani, 2009)finds that ownership, age, and level of innovation results positive change at operational efficiencies Indian pharmaceutical institute and higher R\&D investment has positive role on higher efficiencies. Using DEA approach(Mazumder\& Rajeev,2009) have examined Comparative efficiency of 2492 unbalanced firms during period of 1991-2005.The result of the study claims affirmative technical efficiency change among the companies with large size and new innovation. In contrast, Investment in R\&D is found as low contributing factor in Total factor Productivity growth of sample firms. In the study of Pannu et al., (2010), applied output oriented DEA model and Malmquist productivity index with a view to estimate productivity and efficiency change variation among pharmaceutical companies of India using 10 year data. The two-stage hypothesis found a constructive influence of patents and R\&D investment of output factors such as sales, export, market share, as well as the capacity to attract manufacturing contract among sample pharmaceutical companies of India. Again, it is also claimed that sales growth is motivated by DEA efficiency, firm's size and age.( Pattnayak \& Chadha, 2013)done their research on 76 pharmaceutical companies of India during the year 1991 to 2003 and used the stochastic frontier function (SFA) for the purpose of estimating the technical efficiency improvement among the companies and research findings proclaims that there is higher efficiency growth among the patenting companies comparing with non-patenting companies.(Tripathy, Yadav, \& Sharma, 2013)applied three-stage DEA analysis on 81 firms of Indian pharmaceutical industry to measure the technical efficiency and productivity. This research found that technical efficiency change and productivity is likely to be higher in context of patent regime. Moreover, three-stage analysis results identified that age, R\&D intensity, age, ownership structure, foreign direct investment capital imports are the key elements of technical efficiency of firm.(Mahajan, 2020) has applied Ray and Desli's Malmquist productivity index and its decomposition to assess productivity and efficiency changes among 141 Indian pharmaceutical companies during the period of 2000-2001 to 2014-2015 under variable return to scale(VRS).The study found very low impact of patent regime on productivity performance. Moreover, technological change, fixed asset investment, ownership, R\&D has variable effect on firm'sproductivity. In China, (Liu \& Lyu, 2020) tested a two-stage DEA model on panel data of 28 provinces and regions during the period 2006-2014 aiming to make empirical analysis on technical, pure technical and scale efficiency change considering commercialization and innovation as variable factors. Another research done by (Gaebert \& Staňková, 2020)that deals with measurement of efficiency change of retail and whole sale pharmacies during 2009 to 2016 by consider data of 2751 companies. DEA malmquist approach used to analyse data and the analysis states that there is significant efficiency change in this sector. Again this study come to a conclusion that decreasing number of pharmacies was not caused by government legislation on limiting pharmacies but concentration tendencies of the companies. The study of (Le Tien Muoi, P., Nan, W. C., Khanh, N. H., \& Danh, 2021)used malmquist analysis by taking data of 21 Vietnam medicine companies from year 2012 to 2017.The result finds a positive efficiency performance of medicine Industry. However, further research is proposed with considering socio-economic status, inter-disciplinary factor like health, education, internal environmental factors and macro-economic factors that might produce better efficiency of medicine Industry. In Bangladesh, application of DEA methods on medicine industry was done by the research (Doraisamy, S. M., \& Azad, 2014)taking data of Pharmaceutical companies from the year 2009 to 2013 using annual sales as output factor and fixed asset, salary payments, and raw materials as input factors respectively to calculate efficiency and productivity change of sample companies. The findings of the study postulates that productivity growth is done because of technological advancement. However, Inefficiency of pharmaceutical inefficiency resulted by low scale efficiency rather than pure technical efficiency. The above literature review validates the research on pharmaceutical industry through Malmquist productivity index model in order to measure technical efficiency, pure technical efficiency, pure technical efficiency, scale efficiency and finally total factor productivity change of the said industry in Bangladesh. The primary objective of this study is to analysis of Total factor Productivity TFP of Medicine industry sector in Bangladesh. To achieve this, we use a DEAP Malmquist approach worked on nine privatized pharmaceuticals companies, taking time series data from year 2014 to 2019.

\section{Methods}

Efficiency and productivity is measurable in both parametric and non-parametric approach. One of the popular non-parametric analysis is data envelopment analysis (DEA) used to measure efficiency and productivity of manufacturing industry supported by several research studies. The Malmquist index was developed by the treasured work of (Malmquist, 1953), that upgraded from the work of (Caves et al., 1982) applied to estimate efficiency of a DMU over a given period of time. Data envelopment analysis hosted by Farrell in the year 1957, is a performance measurement tools aided to measure performance of the manufacturer using same production process with multiple inputs and outputs. Both input oriented and output oriented analysis is done through DEA analysis with constant return to scale and variable return to scale which cannot hypnotized generally in any functional form. 
Data of nine leading pharmaceutical companies during 2014-2019 were collected from annual report of the sample companies. Therefore, only nine companies are actually selecting for sample selection considering their market capitalization and dividend payout ratio.

To examine efficiency of sample companies, Malmquist productivity Index analysis was used where constant return to scale (CRS) and output-oriented analysis was considered as these methods are more popular and commonly used by the research for productivity analysis. However, input oriented analysis and variable return to scale analysis are also familiar methods in productivity analysis. Five years' time series data was considered to analyses two input and three output variables. Output factors: Net Sales, Net Income, and Total Asset. Input factors: Operating expenses, and salary expenses.

\section{Results and Analysis}

\subsection{Annual Changes of Total Factor Productivity}

Productivity analysis measures the performance change of selected company in terms of output with a given input variables. Thus, our aim is to assess productivity determinants of the pharmaceutical sector in Bangladesh.

\begin{tabular}{|c|c|c|c|c|c|}
\hline Year & $\begin{array}{c}\text { Efficiency } \\
\text { Change }\end{array}$ & $\begin{array}{c}\text { Technical } \\
\text { Efficiency } \\
\text { Change }\end{array}$ & $\begin{array}{c}\text { Pure } \\
\text { Efficiency } \\
\text { Change }\end{array}$ & $\begin{array}{c}\text { Scale } \\
\text { Efficiency } \\
\text { Change }\end{array}$ & $\begin{array}{c}\text { Total Factor } \\
\text { Productivity } \\
\text { Change. }\end{array}$ \\
\hline $2015-16$ & 1.047 & 0.917 & 1.107 & 0.946 & 0.96 \\
\hline $2016-17$ & 0.864 & 1.071 & 0.908 & 0.952 & 0.925 \\
\hline $2017-18$ & 1.136 & 0.862 & 1.176 & 0.966 & 0.98 \\
\hline $2018-19$ & 0.981 & 0.950 & 0.981 & 0.999 & 0.931 \\
\hline Mean value & 1.002 & 0.947 & 1.038 & 0.965 & 0.949 \\
\hline
\end{tabular}

Table 1: Total Factor Productivity Trend of Pharmaceutical Sector of

Bangladesh during the Period of 2014-2019(DEA: Malmquist Productivity Index)

Table 1 represents trends of change in efficiency factors and Figure 1 shows trend line of Total factor productivity of privately owned pharmaceutical industry of Bangladesh during five years period from 2015-2019.From Table 1 and Figure 1 it is clear that there is no improvement in overall efficiency of this industry with this given sample companies as mean value of productivity is less than one. If we examine mean value of each efficiency change then there is improvement in firms management and maximizing production with defined inputs as its mean efficiency and pure technical efficiency changes by $2 \%$ and $3.8 \%$ respectively within this time period of $2015-2019$.However, the reason behind low performance of the pharmaceutical companies due to low efficiency in using factors of production like capital and technology as mean value of technical efficiency change and scale efficiency change is less than 1 that are the indicators of production and technical efficiency utilization.

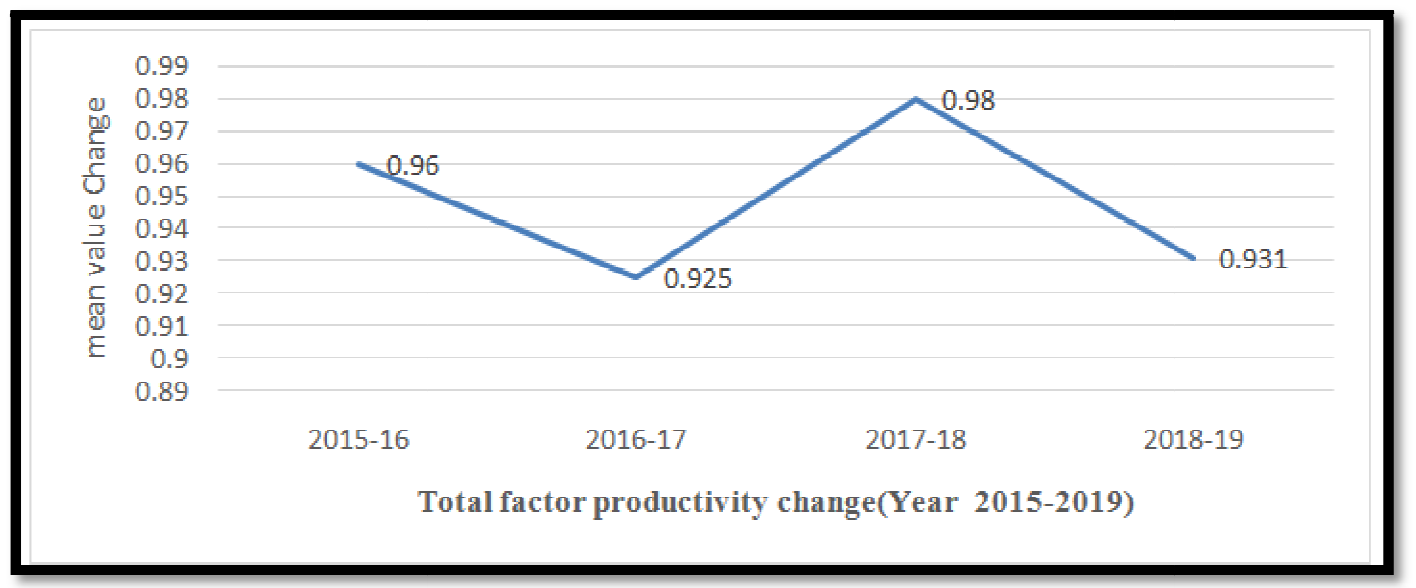

Figure1: Trend Analysis of TFP Changes of Pharmaceutical Sector in Bangladesh (2015-2019)

\subsection{Firm Specific TFP Change of Pharmaceutical Industry}

Table 2 firm's specific performance of this sector. We considered top 9 companies for our study from CSE listed companies. This table 2 proclaims that a major portion of companies are yet to improve their productivity performance from year 2015 to 2019 as the average value of TFPCH is less than one for six sample companies indicating low efficiency in this sector. However, three companies name, Baecon pharma, square pharma and Baximco pharma have shown their overall productivity performance as their total factor productivity increase by $15 \%, 6 \%$ and $5 \%$ respectively during the sample period. 


\begin{tabular}{|c|c|c|c|c|c|}
\hline $\begin{array}{c}\text { Name Of The } \\
\text { Company }\end{array}$ & $\begin{array}{c}\text { Efficiency } \\
\text { Change }\end{array}$ & $\begin{array}{c}\text { Technical } \\
\text { Efficiency } \\
\text { Change }\end{array}$ & $\begin{array}{c}\text { Pure } \\
\text { Efficiency } \\
\text { Change }\end{array}$ & $\begin{array}{c}\text { Scale } \\
\text { Efficiency } \\
\text { Change }\end{array}$ & $\begin{array}{c}\text { Total Factor } \\
\text { Productivity } \\
\text { Change. }\end{array}$ \\
\hline ACI LTD & 0,72 & 1,05 & 0,96 & 0,75 & 0,76 \\
\hline ORION & 0,84 & 0,91 & 0,84 & 1,00 & 0,77 \\
\hline Central & 1,00 & 0,89 & 1,00 & 1,00 & 0,89 \\
\hline Mean & 1,0020 & 0,947 & 1,0380 & 0,965 & 0,949 \\
\hline Globe & 0,94 & 1,03 & 1,00 & 0,94 & 0,97 \\
\hline IBN SINA & 1,09 & 0,90 & 1,09 & 1,00 & 0,98 \\
\hline AMBEE & 1,14 & 0,87 & 1,31 & 0,87 & 0,99 \\
\hline BEXIMCO & 1,00 & 1,05 & 1,00 & 1,00 & 1,05 \\
\hline SQUARE & 1,08 & 0,98 & 1,00 & 1,08 & 1,06 \\
\hline BEACON & 1,33 & 0,86 & 1,21 & 1,10 & 1,15 \\
\hline
\end{tabular}

Table 2: Firm Specific Performance during the Period of 2015 to 2019

\subsection{Firm Specific Operational Efficiency Analysis}

Efficiency change helps to estimate firm's level management capacity to utilize resources for maximum output. Figure 2 showing operational efficiency of efficiency sample pharmaceutical products manufacturing firms. If we evaluate firms individual performances, then we finds that BECON pharma's managerial performance in operation is increased by $33 \%$,Ambee pharmaceutical by $14 \%$,Square pharma by $8 \%$ and IbneSina pharmaceutical limited by $9 \%$ respectively. In contrast, Managerial performance of ACI limited, is poor as efficiency change is decreased by $28 \%$ claiming poor efficiency in managing operations within designated period of time.

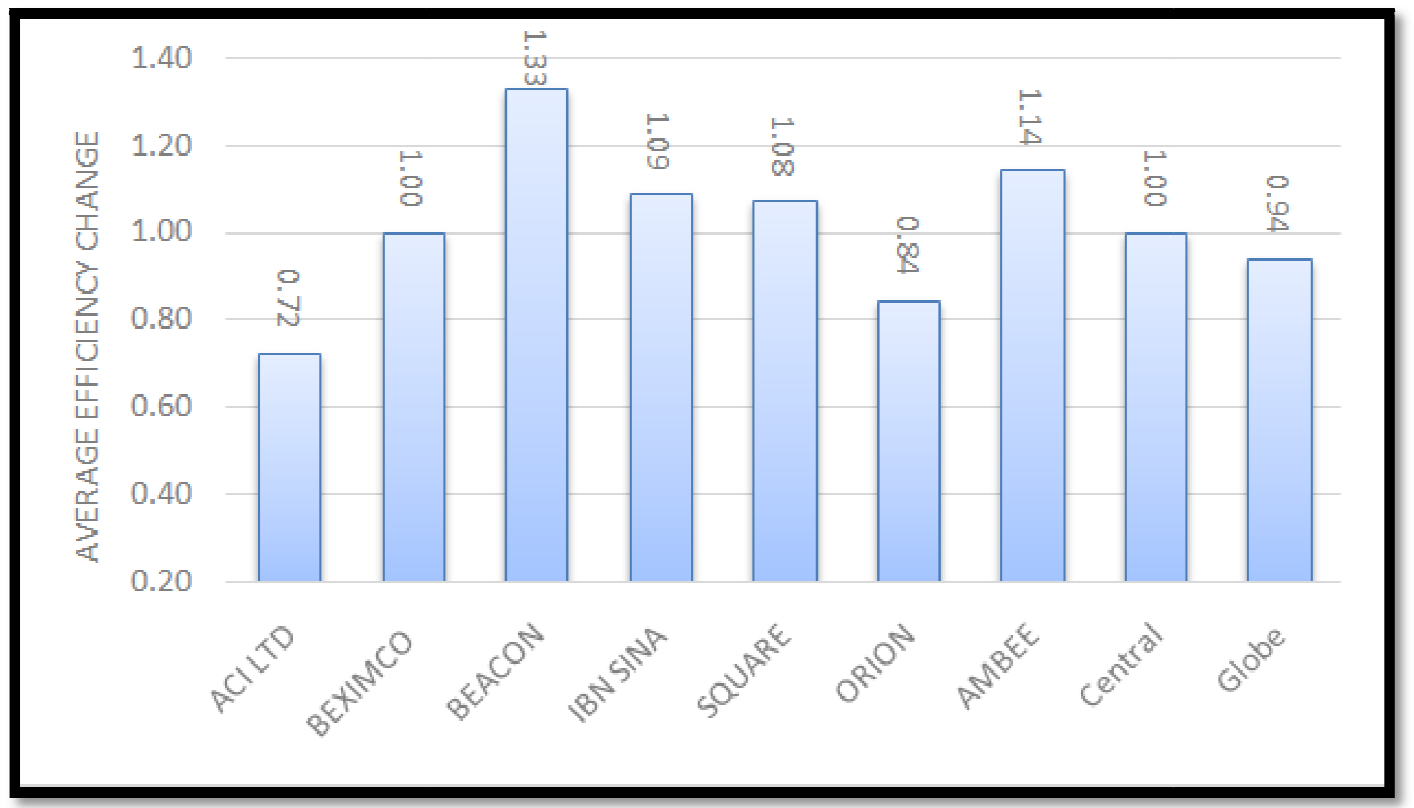

Figure 2: Firm Specific Average Efficiency Changes among Sample Companies

\subsection{Technical Efficiency Change}

A firm can prove their technical efficiency if they can maximize their productivity i.e., output with a given level of input. Fig 3 proclaims firms' individual performance in maximizing output with a constant level of input whose value lies less than one except ACI Limited, Baximco limited and Globe limited indicating poor performance in production efficiency. Additionally, the average mean value of industry is .89 explaining poor performance in maximizing output of the medicine industry as a whole within sample period of 2015-2019. 


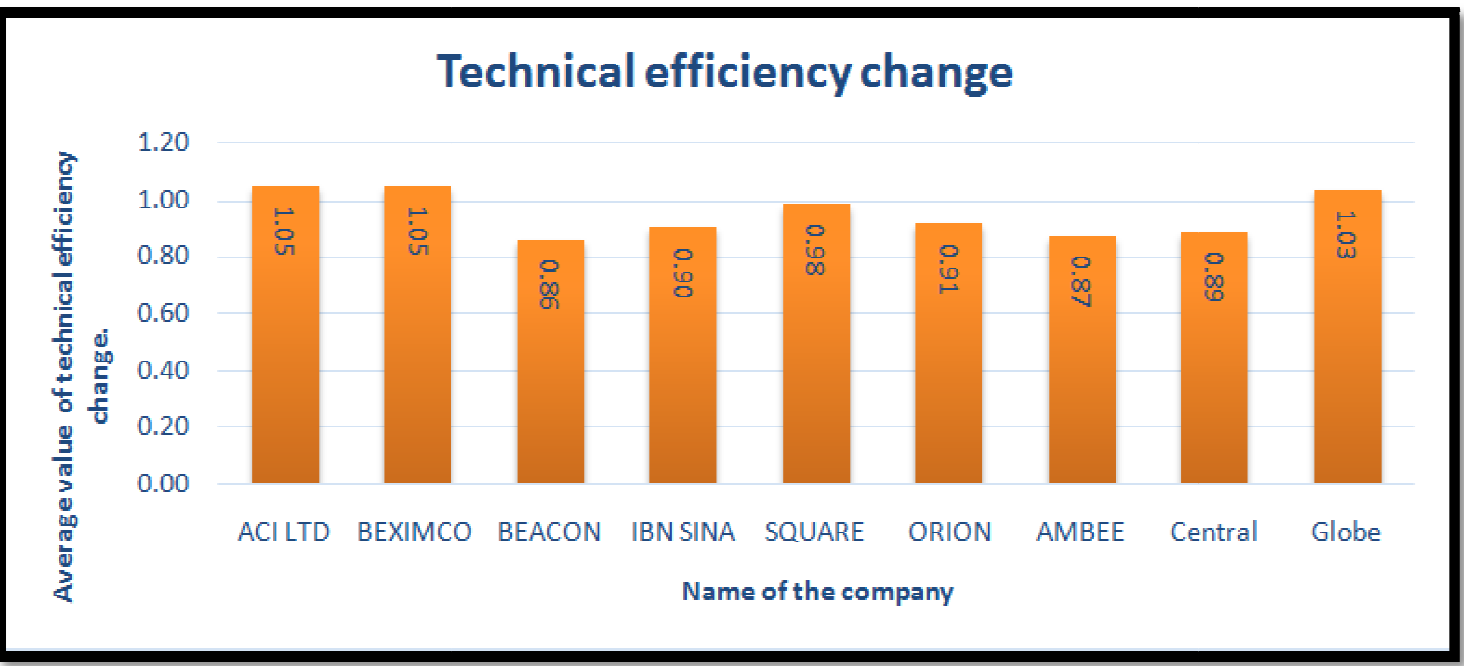

Figure 3: Technical Efficiency Change Estimation of Sample Companies

\subsection{Pure Technical Change from Year 2015-2019}

Technical efficiency of medicine industry is decomposed into pure technical efficiency and scale efficiency where pure technical efficiency measure firms efficiency in input utilization to produce a target level of output.

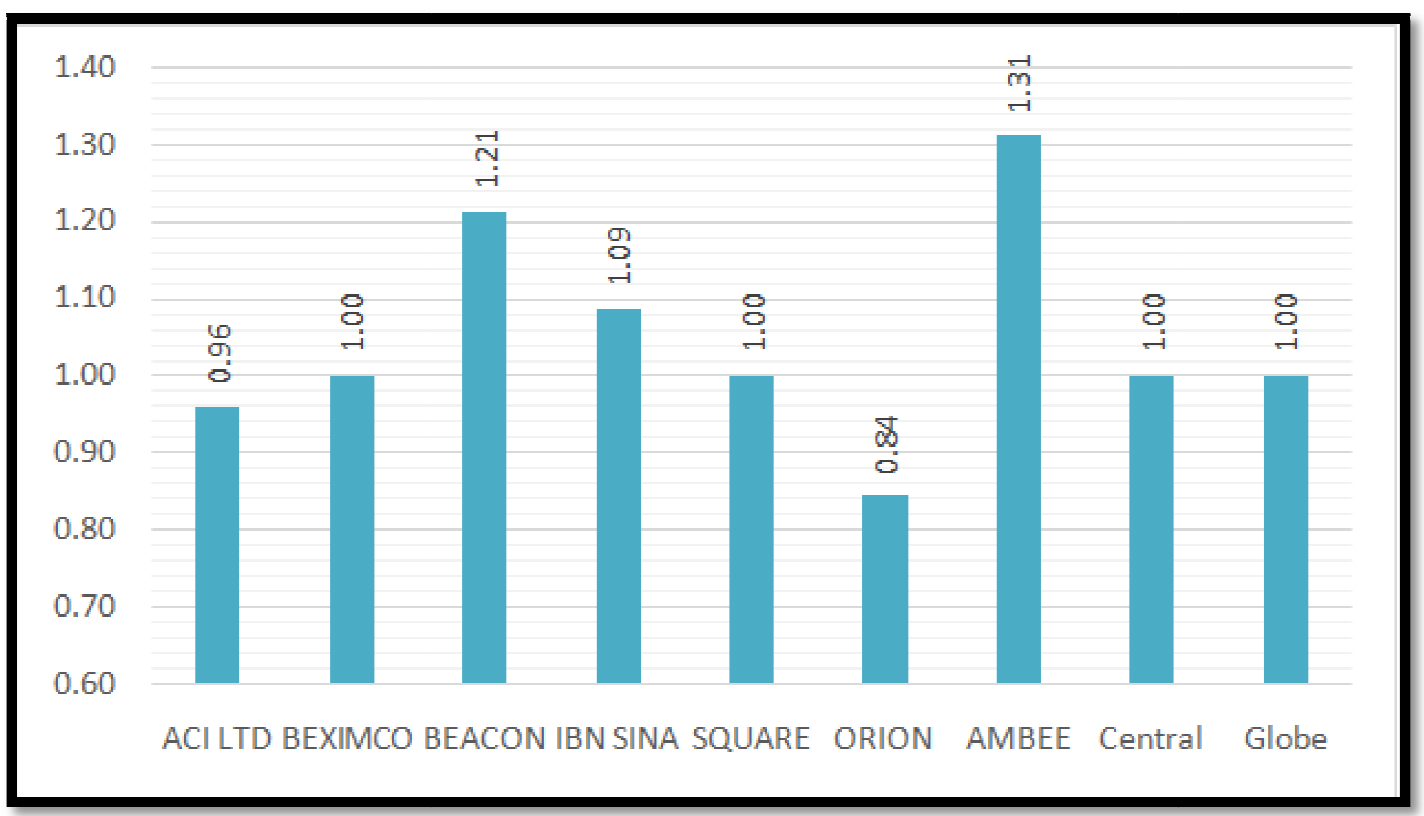

Figure 4: Company Wise Pure Technical-Efficiency Change from Year 2015 to 2019

The above figure 4 is presenting efficiency in input utilization capacity of individual firm. If we compare individual performance pure technical efficiency of AMBEE pharma, BECON pharma and IBN SINA is increased by 31\%, 21\% and 9\% respectively from year 2014 to year 2019.Moreover, Average change of 3.4\% in medicine industry in Bangladesh showing good performance in saving input materials in producing defined level of output within sample period.

\subsection{Scale Efficiency Change (Firm Specific Performance)}

A firm enable to measure relationship between its size and efficient use of input factor in production through measurement of scale efficiency. Figure 5 states scale efficiency change among selected companies listed under Chittagong Stock Exchange. 


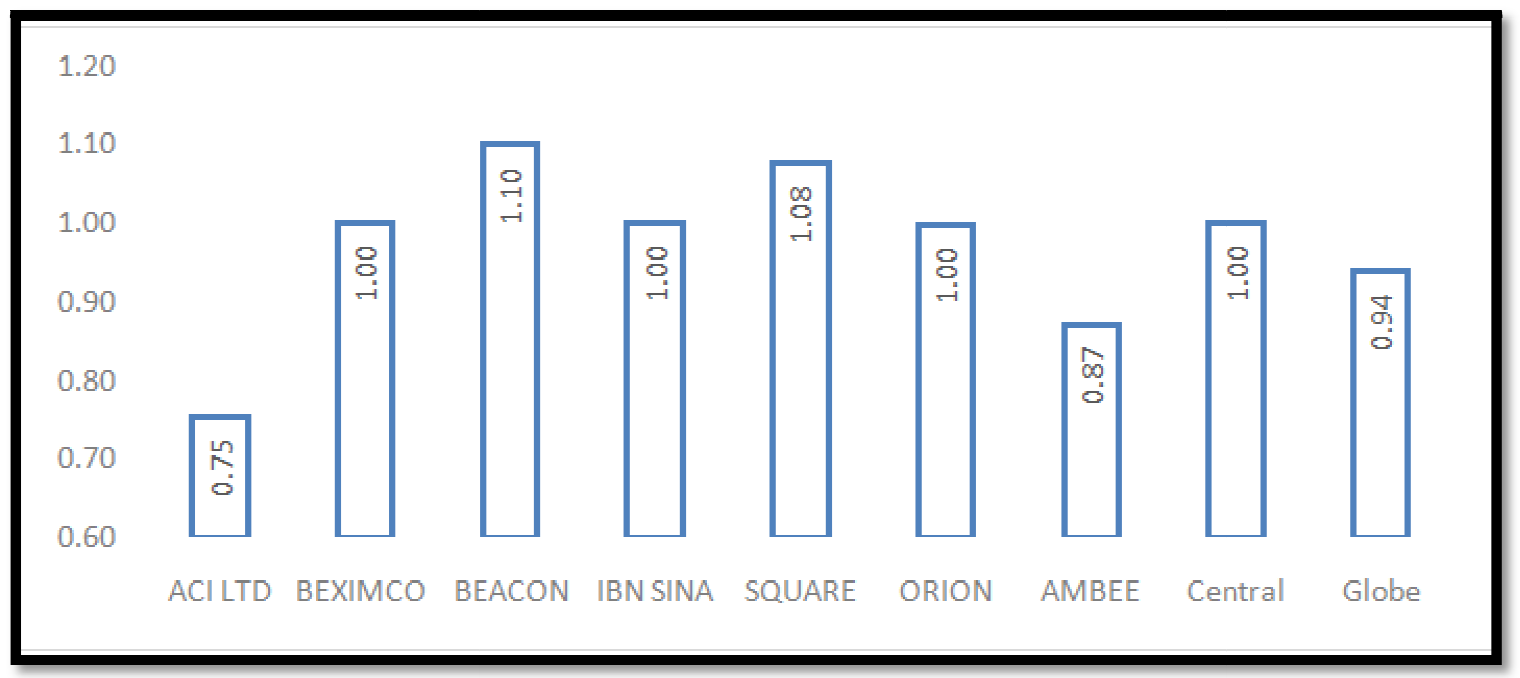

Figure 5 Average Scale Efficiency Change during Sample Period

The average value of scale efficiency change is .965 that claiming low relationship between firm size and efficient use of salaries as well as operating expenses as a input factor for production. In contrast, BECON and SQUARE pharma limited has publicized their efficiency as their scale efficiency change increased by $10 \%$ and $8 \%$ correspondingly.

\subsection{Total Factor Productivity Change}

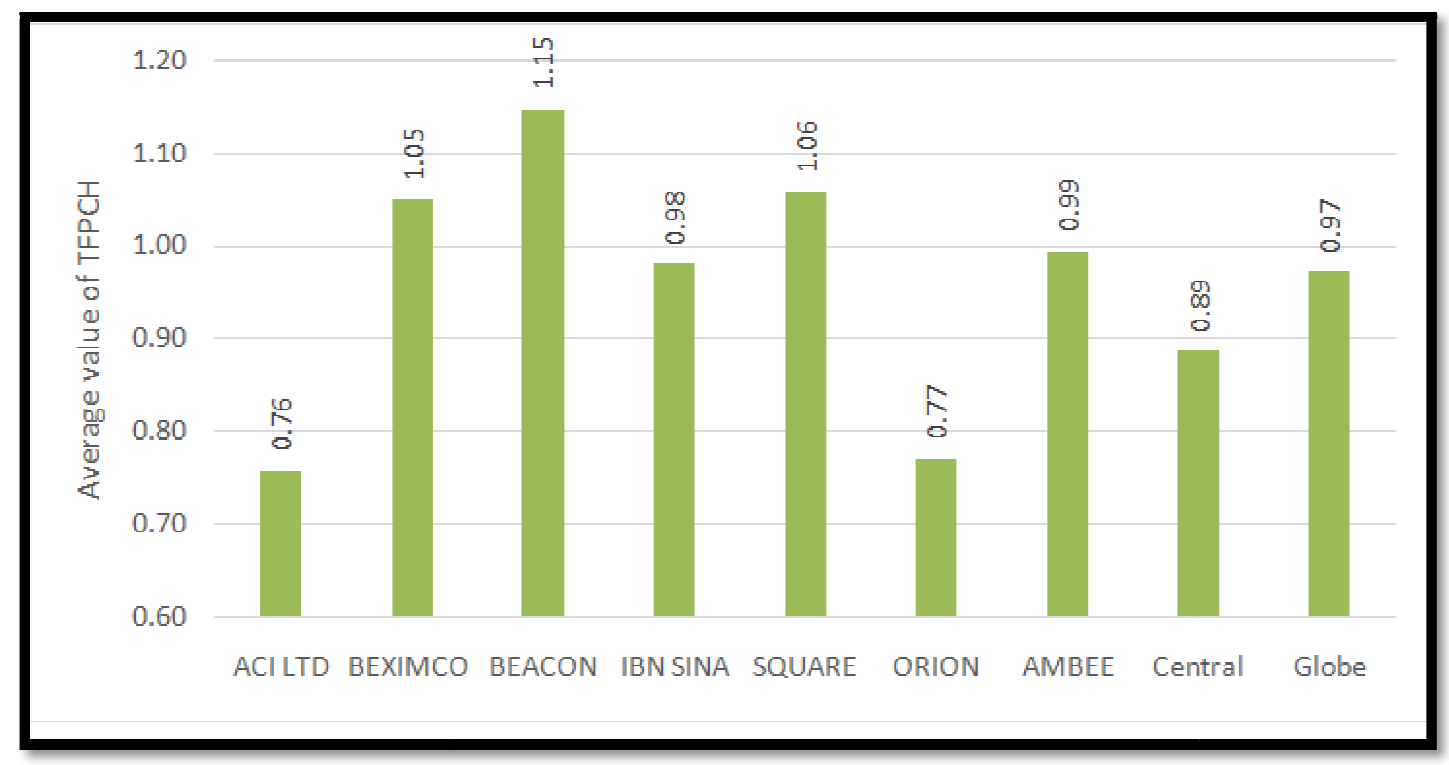

Figure 6: Total Factor Productivity Change during the Period of 2015-2019

Total factor productivity change helps to measure firm's economic efficiency in consideration of all sample inputs and outputs of specified time series data. Figure 6 highlights economic efficiency of individual firm. The average value of total factor productivity change, .949 that is less than 1 explaining economic inefficiency of medicine industry of Bangladesh although BECON pharma, BAXIMCO pharma and SQUARE pharma has gained economic efficiency increase by $15 \%, 5 \%$ and $6 \%$, reflecting firms positive tendency on aggregate efficiency development in privatized medicine sector of Bangladesh.

\section{Discussion}

The main purpose of this research is to evaluate firm's capacity to utilize factors of production to produce maximum output with a given input or improve resource efficiency to produce target amount of output as well of management efficiency of sample companies that led to development of the pharmaceutical industry. Malmquist analysis use to estimate firms allocative and operational efficiency through determining mean value of efficiency change, technical efficiency change, pure technical efficiency change and scale efficiency change. The average value of each efficiency change factor greater than one implies firm's positive efficiency growth and value less than one indicates firms less efficiency in their performance. The result of the study states low efficiency of pharmaceutical industry as total factor productivity change is .94 which is less than one. Moreover, this inefficiency lies because of firms are yet to improve their production performance and size of its operation whose value sight as .947 technical efficiency and .965 in scale efficiency change respectively. This study extended existing research of pharmaceutical industry in Bangladesh by adding net income as output factor along with sales which is more crucial factors of firm's financial performance. The implication of this study 
open space for the future researcher with two stage performance evaluation by considering other influential factors of firm's performance. Furthermore, the policy maker attached with this sector will have scope to get insight on their production and size operation that results making strategy for the future performance along with contribution in revenue earnings of growing economy of Bangladesh.

\section{Concluding Remarks}

Pharmaceutical industry in one of the emerging sectors in Bangladesh for the sake of both health care facilities as well as economic wellbeing as it has enormous potentials to expand its market globally. But, most of the ownership of corporation hold by private sector that aims to maximize profit in spite of noteworthy dependency of nations to ensure sound health care services. Therefore, necessary steps to be considered by the competent authority to ensure sustainable development of this sector. The study assesses managerial operational efficiency, production efficiency, cost saving efficiency and economic efficiency of privatized medicine sector of Bangladesh listed under Chittagong stock exchange (CSE). Findings of the study states that Total factor productivity (TFP) performance change is lack behind perfection due to inefficient use of factors of production like capital and labor and technology though management efficiency and production efficiency is improved. However, Becon pharmaceutical limited, Square pharmaceutical limited and Square pharmaceutical limited have confirmed positive productivity performance during the sample period. The main limitation of this study is that, it limits within Chittagong stock exchange and within fixed input and output variable for productivity measurement. Moreover, it would produce a clear picture of efficiency of medicine industry if study could incorporate individually owned, public limited companies as well as state owned institutions under this study. Therefore, the study suggest individual concentration and central policy formulation that will result positive improvement at operational, technical and economic efficiency at firm level and medicine sector in both public sector in Bangladesh. Finally, this research may be fruitful for the think-tank willing to have further research regarding development of this vital sector of Bangladesh.

\section{References}

i. Charnes, A., Cooper, W. W., \& Rhodes, E. (1978). Measuring the efficiency of decision making units. European Journal of Operational Research, 2(6), 429-444. https://doi.org/10.1016/0377-2217(78)90138-8

ii. Doraisamy, S. M., \& Azad, A. K. (2014). Efficiency Measurement of Pharmaceutical Industry Using the Malmquist Total Productivity Index. 无, 162-173.

iii. Gaebert, T., \&Staňková, M. (2020). Efficiency development in the german pharmaceutical market. ActaUniversitatisAgriculturaeetSilviculturaeMendelianaeBrunensis, 68(5), 877-884.

https://doi.org/10.11118/actaun202068050877

iv. Haque, M., \& Islam, R. (2014). Effects of Supply Chain Management Practices on Customer Satisfaction. 2(1), 113.

v. Islam, M. S., \& Khan, M. S. (2019). The determinants of profitability of the pharmaceutical industry of Bangladesh: A random effect analysis. International Journal of Financial Research, 10(2). https://doi.org/10.5430/ijfr.v10n2p68

vi. Kirigia, J. M., Emrouznejad, A., Sambo, L. G., Munguti, N., \&Liambila, W. (2004). Using data envelopment analysis to measure the technical efficiency of public health centers in Kenya. Journal of Medical Systems, 28(2), 155166. https://doi.org/10.1023/b:joms.0000023298.31972.c9

vii. Le Tien Muoi, P., Nan, W. C., Khanh, N. H., \&Danh, M. H. C. (2021). Mathematical M Odel of B Iofiltration of Voc S : (July), 655-664.

viii. Liu, Z., \&Lyu, J. (2020). Measuring the innovation efficiency of the Chinese pharmaceutical industry based on a dynamic network DEA model. Applied Economics Letters, 27(1), 35-40. https://doi.org/10.1080/13504851.2019.1606402

ix. Mahajan, V. (2020). Is productivity of Indian pharmaceutical industry affected with the introduction of product patent act? Indian Growth and Development Review, 13(1), 227-258. https://doi.org/10.1108/IGDR-11-20180116

x. Nath, S. D., Islam, S., \&Saha, A. K. (2015). Corporate Board Structure and Firm Performance: The Context of Pharmaceutical Industry in Bangladesh. International Journal of Economics and Finance, 7(7), 106-115. https://doi.org/10.5539/ijef.v7n7p106

xi. Pattnayak, S. S., A. C. (2013). Technical Efficiency of Indian Pharmaceutical Firms: A Stochastic Frontier Function Approach. Productivity, 54(1), 54-62. Retrieved from

http://search.ebscohost.com/login.aspx?direct=true \&db=bth\&AN=93477695\&site=ehostlive\&authtype $=$ sso\&custid $=$ ns 192260

xii. Rajeev, M. (n.d.). A Comparative Analysis of Efficiency and Productivity of the Indian Pharmaceutical Firms : A Malmquist-Meta- Frontier Approach.

xiii. Rashid, M. (2014). Pharmaceutical Sector of Bangladesh: Prospects and Challenges Executive Summary. BRAC Business School BRAC University EMBA, (14174028), 2019. Retrieved from https://pdfs.semanticscholar.org/8680/3a4e68726a1ff3d48c92534da36e2b4137a1.pdf

xiv. Saranga, H., \&Phani, B. V. (2009). Determinants of operational efficiencies in the Indian pharmaceutical industry. International Transactions in Operational Research, 16(1), 109-130.

https://doi.org/10.1111/j.1475-3995.2009.00668.x 
xv. Tripathy, I. G., Yadav, S. S., \& Sharma, S. (2013). Efficiency and productivity in the process and product patent regimes: empirical evidence from the Indian pharmaceutical industry. International Journal of Economics and Business Research, 6(1), 1. https://doi.org/10.1504/ijebr.2013.054838

xvi. Khan, S. (2007) 'Frontier approach to the evaluation of efficiency and productivity in the Indian pharmaceutical industry', Unpublished PhD thesis, Indian Institute of Technology Delhi, New Delhi, India.

xvii. Pannu, H. S., Farooquie, J. A., \& Kumar, U. D. (2010). Impact of innovation on the performance of Indian pharmaceutical industry using Data Envelopment Analysis

\section{Appendix}

Name of the top nine pharmaceutical companies listed in CSE:

- ACI Limited,

- Beximco Pharmaceuticals Ltd,

- Beacon Pharmaceuticals Limited,

- Ibn SinaPharmaceuticals Ltd,

- Square Pharmaceuticals Ltd,

- Orion Pharmaceuticals Ltd.

- Ambee Pharmaceuticals Ltd,

- Central Pharmaceuticals Limited,

- Globe Pharmaceuticals Ltd.

\section{Results from DEAP Version 2.1}

Instruction file $=$ eg3-ins.txt

Data file = eg3-data.txt

Output orientated Malmquist DEA

\section{DISTANCES SUMMARY}

year $=1$

firm crs te rel to tech in yr vrs

no. $* * * * * * * * * * * * * * * * * * * * * * * * *$ te

$\mathrm{t}-1 \quad \mathrm{t} \quad \mathrm{t}+1$

$\begin{array}{lllll}1 & 0.000 & 0.395 & 0.384 & 0.572\end{array}$

$\begin{array}{lllll}2 & 0.000 & 1.000 & 1.212 & 1.000\end{array}$

$\begin{array}{lllll}3 & 0.000 & 0.318 & 0.479 & 0.465\end{array}$

$\begin{array}{lllll}4 & 0.000 & 0.717 & 0.625 & 0.719\end{array}$

$\begin{array}{lllll}5 & 0.000 & 0.747 & 0.735 & 1.000\end{array}$

$\begin{array}{lllll}6 & 0.000 & 1.000 & 1.053 & 1.000\end{array}$

$\begin{array}{lllll}7 & 0.000 & 0.333 & 0.327 & 0.339\end{array}$

$\begin{array}{lllll}8 & 0.000 & 1.000 & 2.187 & 1.000\end{array}$

$\begin{array}{lllll}9 & 0.000 & 1.000 & 0.981 & 1.000\end{array}$

$$
\begin{array}{ccccc}
\text { mean } \quad 0.000 & 0.723 & 0.887 & 0.788 \\
\text { year }= & 2
\end{array}
$$

firm crs te rel to tech in yr vrs

no. $* * * * * * * * * * * * * * * * * * * * * * * * *$ te

$\mathrm{t}-1 \quad \mathrm{t} \quad \mathrm{t}+1$

$\begin{array}{lllll}1 & 0.299 & 0.296 & 0.259 & 0.587\end{array}$

$\begin{array}{lllll}2 & 0.983 & 1.000 & 0.960 & 1.000\end{array}$

$\begin{array}{lllll}3 & 0.275 & 0.374 & 0.324 & 0.416\end{array}$

$\begin{array}{lllll}4 & 0.718 & 0.625 & 0.792 & 0.662\end{array}$

$\begin{array}{lllll}5 & 1.040 & 1.000 & 0.877 & 1.000\end{array}$

$\begin{array}{lllll}6 & 1.148 & 1.000 & 1.318 & 1.000\end{array}$

$\begin{array}{lllll}7 & 0.311 & 0.489 & 0.404 & 1.000\end{array}$

$\begin{array}{lllll}8 & 0.928 & 1.000 & 0.962 & 1.000\end{array}$ 


$$
\begin{aligned}
& \begin{array}{lllll}
9 & 1.203 & 1.000 & 0.917 & 1.000
\end{array} \\
& \begin{array}{lllll}
\text { mean } & 0.767 & 0.754 & 0.757 & 0.852
\end{array} \\
& \text { year }=3 \\
& \mathrm{t}-1 \quad \mathrm{t} \quad \mathrm{t}+1 \\
& \begin{array}{lllll}
\text { mean } & 0.839 & 0.717 & 0.913 & 0.799
\end{array} \\
& \text { year }=4
\end{aligned}
$$

firm crs te rel to tech in yr vrs no. $* * * * * * * * * * * * * * * * * * * * * * * * *$ te

$$
\mathrm{t}-1 \quad \mathrm{t} \quad \mathrm{t}+1
$$

$\begin{array}{lllll}1 & 0.126 & 0.110 & 0.115 & 0.502\end{array}$

$\begin{array}{lllll}2 & 1.198 & 1.000 & 1.110 & 1.000\end{array}$

$\begin{array}{lllll}3 & 0.764 & 1.000 & 1.026 & 1.000\end{array}$

$\begin{array}{lllll}4 & 0.803 & 1.000 & 1.185 & 1.000\end{array}$

$\begin{array}{lllll}5 & 0.848 & 1.000 & 1.073 & 1.000\end{array}$

$\begin{array}{lllll}6 & 0.582 & 0.563 & 0.601 & 0.579\end{array}$

$\begin{array}{lllll}7 & 0.378 & 0.530 & 0.549 & 1.000\end{array}$

$\begin{array}{lllll}8 & 0.811 & 0.871 & 0.856 & 1.000\end{array}$

$\begin{array}{lllll}9 & 1.000 & 1.000 & 1.238 & 1.000\end{array}$

$$
\begin{array}{ccccc}
\text { mean } 0.723 \quad 0.786 & 0.861 & 0.898 \\
\text { year }= & 5
\end{array}
$$

firm crs te rel to tech in yr vrs no. $* * * * * * * * * * * * * * * * * * * * * * * * *$ te

$$
\mathrm{t}-1 \quad \mathrm{t} \quad \mathrm{t}+1
$$

$\begin{array}{lllll}1 & 0.097 & 0.108 & 0.000 & 0.486\end{array}$

$\begin{array}{lllll}2 & 1.025 & 1.000 & 0.000 & 1.000\end{array}$

$\begin{array}{lllll}3 & 1.009 & 1.000 & 0.000 & 1.000\end{array}$

$\begin{array}{lllll}4 & 0.986 & 1.000 & 0.000 & 1.000\end{array}$

$\begin{array}{lllll}5 & 0.948 & 1.000 & 0.000 & 1.000\end{array}$

$\begin{array}{lllll}6 & 0.473 & 0.502 & 0.000 & 0.505\end{array}$

$\begin{array}{lllll}7 & 0.548 & 0.567 & 0.000 & 1.000\end{array}$

$\begin{array}{lllll}8 & 1.029 & 1.000 & 0.000 & 1.000\end{array}$

$\begin{array}{lllll}9 & 0.768 & 0.781 & 0.000 & 1.000\end{array}$

$$
\begin{array}{lllll}
\text { mean } & 0.765 & 0.773 & 0.000 & 0.888
\end{array}
$$

[Note that $t-1$ in year 1 and $t+1$ in the final year are not defined]

\section{MALMQUIST INDEX SUMMARY}

year $=2$ 
firm effch techch pech sech tfpch

$\begin{array}{llllll}1 & 0.750 & 1.018 & 1.026 & 0.731 & 0.764\end{array}$

$\begin{array}{lllllll}2 & 1.000 & 0.901 & 1.000 & 1.000 & 0.901\end{array}$

$\begin{array}{llllll}3 & 1.174 & 0.700 & 0.894 & 1.313 & 0.822\end{array}$

$\begin{array}{llllll}4 & 0.872 & 1.148 & 0.921 & 0.947 & 1.001\end{array}$

$\begin{array}{llllll}5 & 1.338 & 1.028 & 1.000 & 1.338 & 1.376\end{array}$

$\begin{array}{lllllll}6 & 1.000 & 1.044 & 1.000 & 1.000 & 1.044\end{array}$

$\begin{array}{llllll}7 & 1.467 & 0.806 & 2.952 & 0.497 & 1.182\end{array}$

$\begin{array}{llllll}8 & 1.000 & 0.652 & 1.000 & 1.000 & 0.652\end{array}$

$\begin{array}{llllll}9 & 1.000 & 1.107 & 1.000 & 1.000 & 1.107\end{array}$

$\begin{array}{llllll}\text { mean } & 1.047 & 0.917 & 1.107 & 0.946 & 0.960\end{array}$

$$
\text { year }=3
$$

firm effch techch pech sech tfpch

$\begin{array}{llllll}1 & 0.438 & 1.134 & 0.772 & 0.567 & 0.497\end{array}$

$\begin{array}{lllllll}2 & 1.000 & 1.266 & 1.000 & 1.000 & 1.266\end{array}$

$\begin{array}{llllll}3 & 0.694 & 1.132 & 0.690 & 1.005 & 0.785\end{array}$

$\begin{array}{llllll}4 & 1.276 & 0.790 & 1.252 & 1.019 & 1.008\end{array}$

$\begin{array}{llllll}5 & 0.883 & 1.141 & 1.000 & 0.883 & 1.008\end{array}$

$\begin{array}{lllllll}6 & 1.000 & 0.918 & 1.000 & 1.000 & 0.918\end{array}$

$\begin{array}{llllll}7 & 0.780 & 1.041 & 0.625 & 1.247 & 0.812\end{array}$

$\begin{array}{llllll}8 & 1.000 & 1.125 & 1.000 & 1.000 & 1.125\end{array}$

$\begin{array}{llllll}9 & 1.000 & 1.177 & 1.000 & 1.000 & 1.177\end{array}$

$\begin{array}{llllll}\text { mean } & 0.864 & 1.071 & 0.908 & 0.952 & 0.925\end{array}$

year $=4$

firm effch techch pech sech tfpch

$\begin{array}{llllll}1 & 0.846 & 1.131 & 1.107 & 0.765 & 0.957\end{array}$

$\begin{array}{lllllll}2 & 1.000 & 1.104 & 1.000 & 1.000 & 1.104\end{array}$

$\begin{array}{llllll}3 & 3.860 & 0.699 & 3.484 & 1.108 & 2.698\end{array}$

$\begin{array}{llllll}4 & 1.253 & 0.800 & 1.206 & 1.039 & 1.002\end{array}$

$\begin{array}{llllll}5 & 1.132 & 0.848 & 1.000 & 1.132 & 0.961\end{array}$

$\begin{array}{llllll}6 & 0.563 & 0.776 & 0.579 & 0.972 & 0.437\end{array}$

$\begin{array}{lllllll}7 & 1.390 & 0.710 & 1.599 & 0.869 & 0.986\end{array}$

$\begin{array}{lllllll}8 & 0.871 & 0.823 & 1.000 & 0.871 & 0.717\end{array}$

$\begin{array}{lllllll}9 & 1.000 & 0.984 & 1.000 & 1.000 & 0.984\end{array}$

$\begin{array}{llllll}\text { mean } & 1.136 & 0.862 & 1.176 & 0.966 & 0.980\end{array}$

$$
\text { year }=5
$$

firm effch techch pech sech tfpch

$\begin{array}{llllll}1 & 0.981 & 0.929 & 0.969 & 1.012 & 0.911\end{array}$

$\begin{array}{llllll}2 & 1.000 & 0.961 & 1.000 & 1.000 & 0.961\end{array}$

$\begin{array}{llllll}3 & 1.000 & 0.992 & 1.000 & 1.000 & 0.992\end{array}$

$\begin{array}{llllll}4 & 1.000 & 0.912 & 1.000 & 1.000 & 0.912\end{array}$

$\begin{array}{llllll}5 & 1.000 & 0.940 & 1.000 & 1.000 & 0.940\end{array}$

$\begin{array}{llllll}6 & 0.892 & 0.939 & 0.872 & 1.022 & 0.837\end{array}$

$\begin{array}{llllll}7 & 1.070 & 0.965 & 1.000 & 1.070 & 1.033\end{array}$

$\begin{array}{llllll}8 & 1.148 & 1.024 & 1.000 & 1.148 & 1.175\end{array}$

$\begin{array}{llllll}9 & 0.781 & 0.891 & 1.000 & 0.781 & 0.696\end{array}$

$\begin{array}{llllll}\text { mean } & 0.981 & 0.950 & 0.981 & 0.999 & 0.931\end{array}$ 
MALMQUIST INDEX SUMMARY OF ANNUAL MEANS

year effch techch pech sech tfpch

$\begin{array}{llllll}2 & 1.047 & 0.917 & 1.107 & 0.946 & 0.960\end{array}$

$\begin{array}{lllllll}3 & 0.864 & 1.071 & 0.908 & 0.952 & 0.925\end{array}$

$\begin{array}{lllllll}4 & 1.136 & 0.862 & 1.176 & 0.966 & 0.980\end{array}$

$\begin{array}{lllllll}5 & 0.981 & 0.950 & 0.981 & 0.999 & 0.931\end{array}$

$\begin{array}{llllll}\text { mean } & 1.002 & 0.947 & 1.038 & 0.965 & 0.949\end{array}$

MALMQUIST INDEX SUMMARY OF FIRM MEANS

firm effch techch pech sech tfpch

$\begin{array}{llllll}1 & 0.723 & 1.050 & 0.960 & 0.753 & 0.758\end{array}$

$\begin{array}{lllllll}2 & 1.000 & 1.049 & 1.000 & 1.000 & 1.049\end{array}$

$\begin{array}{llllll}3 & 1.332 & 0.861 & 1.211 & 1.100 & 1.146\end{array}$

$\begin{array}{llllll}4 & 1.087 & 0.902 & 1.086 & 1.001 & 0.980\end{array}$

$\begin{array}{llllll}5 & 1.076 & 0.984 & 1.000 & 1.076 & 1.058\end{array}$

$\begin{array}{lllllll}6 & 0.842 & 0.914 & 0.843 & 0.998 & 0.770\end{array}$

$\begin{array}{llllll}7 & 1.142 & 0.871 & 1.311 & 0.871 & 0.994\end{array}$

$\begin{array}{lllllll}8 & 1.000 & 0.886 & 1.000 & 1.000 & 0.886\end{array}$

$\begin{array}{llllll}9 & 0.940 & 1.034 & 1.000 & 0.940 & 0.972\end{array}$

mean $1.002 \quad 0.947 \quad 1.038 \quad 0.965 \quad 0.949$

[Note that all Malmquist index averages are geometric means] 